\title{
Public Expenditures and Receipts in France
}

\author{
By Charles Gide \\ Professor in the Faculty of Law in the University of Paris
}

$\mathrm{B}^{\mathrm{H}}$ EFORE the war the budget of expenditures had gradually and rapidly increased from one billion francs in 1834 to a little more than five billions on the eve of the war. ${ }^{1}$ This figure of five billions had already disturbed public opinion, for it represented more than 130 francs per capita in population, and the financiers and economists said that the limit of the taxpayers' capacity had been reached, a remark which today makes one smile. The budget of 1920 is exactly ten times as much, or fifty billion francs. It is true that this has been brought down to a somewhat lower figure, but only by rather unsound economics.

This enormous total can be divided into four parts: dated debt, there was a short-term debt (Treasury Bonds) and various other obligations of the state (particularly for the guarantee of railroad deficits), so that the service of interest of the public debt amounted to one billion francs in round numbers, without counting what is called the life debt, that is, $\mathbf{3 4 0}$ million francs annually for civil and military pensions. Therefore, it was about one-fourth of the budget of expenditures. This debt was at this date already considered as excessive and as handicapping France in international competition. Indeed, it exceeded the debts of all the other countries in the world, without exception.

And so it is that with financial con-

(a) Interest of the public debt; about

(b) Military expenditures

(c) Civil service

12 billions

(d) Reconstruction of the devastated regions and war pensions

6
7
20

45 “

Interests of the Public Debt

Before the war, the consolidated public debt (that is, in perpetual annuities or redeemable at long term) amounted to 25 billion francs capital (in round numbers), the interest and redemption of which (the latter very trifling) was 760 million francs. This debt in almost its entirety was the result of past wars and particularly of that of 1870-71.

But at the same time as the consoli-

1 Here are the progressions at the rate of a million:

$\begin{array}{llll}1834 & 1,007 & \text { million francs } \\ 1866 & 2,018 & \text { " } & \text { “ } \\ 1888 & 3,107 & \text { “ } & \text { “ } \\ 1909 & 4,141 & \text { “ } & \text { “ } \\ 1914 & 5,091 & \text { " } & \text { “ }\end{array}$

ditions already very burdensome, France found herself surprised by the Great War, which inflicted on her about 120 billion francs of military war expenses, properly called, and an equal amount of indirect expenses, payments to families, subsidies, pensions and interest (account established December $31,1920)$. It goes without saying that France has not been able to make provision for these enormous expenditures with her taxes. She received in taxes in the course of eight years (August, 1914-December, 1920) about 46 billion francs; all the rest, that is, more than 200 billion francs, was obtained by various kinds of loans. Following are the various categories of the war loans: 
(a) Loans in consolidated annuities (six loans)

(b) Loans in short-term obligations (National Defense Bonds)

(c) Loan from the Bank of France

(d) Loans from foreign countries

\begin{tabular}{ccc}
86 & billion & crancs \\
52 & “ & “ \\
26 & “ & “ \\
\hline 34 & & \\
198 & “
\end{tabular}

The 25 billion francs of consolidated debt previous to the war are therefore increased by (or will be in proportion to the loans for consolidation) 200 billions and are thus brought to 225 billions and even to a considerably higher figure because all the loans effective to date were issued below par (except the last of November, 1920, which was issued at six per cent at par). And so it is that the figure of 86 billions of consolidated loans given above represents in fact what the State has received but not what it is pledged to pay when the time comes. The nominal amount of these six loans reaches 111 billions. The consolidated debt of France therefore (that before the war and that after the war), amounts at present to 136 billion francs and the total public debt to more than 300 billions, if one takes in account all her other obligations. ${ }^{2}$ This debt is unfortunately destined to increase for many years, as we shall see at the end of this article.

The interest of this enormous debt, figured at six per cent and without redemption, will amount to about 18 billions, in fact, but, in the figure in the budget of 1920 , does not go beyond 12 billions because the interest of the last

\footnotetext{
${ }^{2}$ It is also necessary to remark that in the above outline the debt to foreign countries is estimated at par; if it were estimated at the present rate of exchange (February, 1921), it would be necessary to estimate it at about 90 billions.

This is how it is divided:

Debt to the United States 3,500 million dollars

“" "England $\quad 570$ million pounds

“ " Spain 600 million pesetas

“ " other countries 1,000 million francs

These debts are the state debts only and do not include the loans made in the United States for French merchants, probably 5 billion dollars.
}

loan and foreign loans is not included in it and the debt to the Bank of France is only encumbered with a negligible interest, and the interest of loans previous to the war was only three per cent.

\section{Military Expenses}

In the budget of 1913, which was the last administered before the war, the military expenses were figured as follows:

$$
\begin{aligned}
& \text { Army ........ } 983 \text { millions } \\
& \text { Navy ........ } 488 \text { " } \\
& 1,471 \text { “ }
\end{aligned}
$$

The budget of 1914, which was voted on seven months late, in July, 1914, on the eve of the declaration of war, and which therefore remained on paper, involved an enormous increase.

$$
\begin{aligned}
& \text { Army .........2,052 millions }{ }^{3} \\
& \text { Navy ........ } 513 \text { " } \\
& 2,565 \text { “ }
\end{aligned}
$$

The budget of 1921 is figured as follows (figures that are very uncertain, however):

$$
\begin{aligned}
& \text { Army ...... .5,288 million francs } \\
& \text { Navy .... }
\end{aligned}
$$

Such a figure is indeed made in order to confound those who expected a reduction, from the war, of war expenses. Without wishing to try to justify it, even by the example of the other great powers who did very much the same thing, the explanation is this.

3 This figure of 2,052 millions included, of course, 848 million extra expenses caused by the establishment of the three years military service, expenses which would not be renewed in the future, it was said. 
The expenses of the army (1921 budget) include:

900 million francs for Syria

600 " " " Morocco

700 " " " the occupation of the German provinces of the Rhine, these expenses having to be paid by Germany.

These three together represent more than 2 billions, which deducted from the total war expenditures of 5,288 millions, leave for the expenditures of the home army about 3 billions. Now if this figure is compared with that before the war (about two billions), it will be seen that the increase is far less than the rise in prices. If the index number for France indicates a rise of 350 per cent, the conclusion will be that a rise of 50 per cent for the war expenditures is really modest.

It must be remembered that the pay of soldiers and officers was practically tripled (a sergeant receives today 8,000 francs instead of 2,100 before the war, a captain 16,000 instead of 6,000 ), and even these amounts are considerably lower than those of foreign armies.

Along with the military expenses, it would be proper to record the pensions due wounded soldiers and the families of the dead, which amount at present to 3,500 millions and possibly to 4,500 millions on the day when they are definitely settled. But as they have been charged to Germany, by the Treaty of Versailles, we shall find them later on page 154 .

As to the budget of the navy, which from 500 millions in 1914 has only risen to 852 millions, such a small increase can only be explained by a complete halt in naval construction in France, which is indeed the case. ${ }^{5}$

${ }^{4}$ In the proposed budget of 1921, the amount asked for Syria and the Orient is raised to 888 millions; for Morocco to 591 millions, doubtless parliament will make a considerable reduction.

' It is interesting to compare with this modest figure that of the naval expenses of the United States 1920-1921.

\section{Civil Service}

We include under this head everything that comes in the province of the state, except the two preceding headings (public debt and military expenditures). Before the war this service amounted in the budget to about 2,300 millions and therefore represented less than half of the whole budget (45 per cent). In the budget of 1920, these expenses increased to about eight billions, an increase of 250 per cent, a little less than three times as much. It does not exceed and even is far from reaching the increase in the cost of living, although the number of officials has increased very much, as it has in all the belligerent countries.

Of all services, that which has increased the most (and this is a happy consolation among so many others that are disheartening), is that of public instruction. This is not saying that it figures for a very large share in the budget, not even one-tenth of the service of the public debt; but if the figure is humiliating compared to other expenses, it appears, on the other hand, very creditable when compared with what it was formerly. Following are some dates which mark the stages of the budget of public instruction:

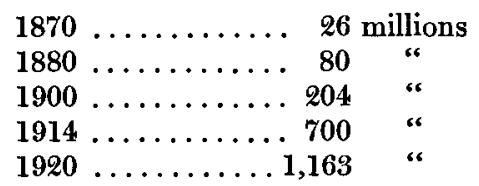

The largest part of this budget is absorbed by primary instruction (780 million francs). Higher education is still very poorly endowed (65 millions).

A public service which would fill great needs, especially at this time, and which the state can not fulfil for lack of resources, is the public works, the tools of the nation. Already quite insufficient and backward 
before the war, today it has to be constructed all over again-railroads, highways, canals, ports, hydro-electric installations, public hygiene, and especially the building of new houses to mitigate the frightful crisis in lodging accommodations. The state is obliged to rely on individual initiative to take care of these urgent necessities. The railroads, the mail and telegraph systems, in spite of the almost double charges, claim enormous deficits; the railroads, two billion francs; the postal and telegraph systems, 500 millions.

\section{Reconstruction of the Devastated REGIONS}

Whatever may be the sympathies which the devastation of the richest region of France awakened in foreign countries and particularly in the United States, one is not sufficiently aware of the task that falls on France if she is not paid by Germany and aided by her Allies. The amount of damages which at first had only been estimated at 25 billion francs has increased by successive estimates to 130 billions. ${ }^{6}$ Such an increase in the estimates evidently runs the risk of causing them to be suspected, and we have from the beginning expressed regret that these estimates were not entrusted to neutral experts and even debated with the Germans. However, it is necessary to note that this increase in the estimates made since the armistice does not exceed the rise in prices; it is incontestable that the cost of construction has increased four-fold and even five-fold, and so it is not surprising that if the costs of reconstruction were estimated at 25

${ }^{8}$ Including only the damages in the devastated parts of France. Adding to this the damages on the sea and in foreign lands the total exceeds 140 billion francs. In addition to this the capitalization of the war payments to families reaches the sum of 60 billion franes. This makes a general total of 200 billion francs. billions during the war, they had increased to 130 billions today.

The French Government has pledged itself by a law of 1917, law of national solidarity, a very generous but rather rash law, to completely indemnify the victims on recovering the German debt. This means that the government must pay at once, when it does not yet know when or how it will be paid itself. It is a really tragic financial situation. The government must enter on the budget 15 to 20 billion francs (21 billions in the budget of 1920) while it has not yet received anything from Germany in money, only in natural restitutions (which are quite considerable).

The government does not wish to make its taxpayers (among whom are the victims themselves) support the payment of these indemnities. Therefore, it can only ask for payment by loans. And so it is that its enormous debt increases every year to the extent of the whole amount of this deficit, and it will continue to increase for a long time to come; for even supposing that Germany accepts the conditions that were just imposed on her by the Paris Conference (February, 1921), she will only have to pay, by annuities at first of two billions marks gold, ${ }^{7}$ then of three, of four, of five and finally of six, beginning with 1931, of which France will collect only 52 per cent. ${ }^{8}$ We do not criticize, nor do we think

${ }^{7}$ The mark gold is worth 1.24 francs gold, and therefore, at the present rate of exchange, about 3.50 francs paper. The two annuities of two billions marks gold, afterward the three annuities of three billions marks gold, that is in all, 13 billions, of which a little less than seven billions is for France, would furnish her accordingly with 24 to 25 billions of francs in five years, while the reconstruction of the devastated regions for these five years will without doubt be triple, and it will not be finished at that date.

${ }^{8}$ In addition, it is true, she will have an equal share in the annuity eventual of 12 per cent in exports. 
that a heavier burden should be imposed on Germany, but it is none the less true that the period of the enormous deficit for France may last a very long time. Yesterday (February 6, 1921), the Premier, M. Briand, in the Chambre, contemplated the eventuality of an annual loan of a dozen billions for about ten years, which would increase our public debt to a figure of more than 400 billion francs! Let us hope that we shall avoid such a calamity, a calamity that can only be avoided when France finds a way to discount the annuities that are to fall due, in the form of some capital that can be immediately realized. For this there is needed someone who would be willing to advance the money owed by Germany, and there is no one but the United States that could assume this rôle of saviour.

\title{
The Sources of the Receipts of the French Government in 1920
}

\author{
By Gaston Jeze \\ Professor of Finances in the Faculty of Law in the University of Paris
}

$\mathrm{T}$ THE year 1920 marks in France a very important date. Taxes were suddenly carried to an enormous figure. New taxes of more than eight billions (estimated) were created by the laws of June 25, 1920, and of July 31, 1920. The budget for 1920 valued the "ways and means applicable to the ordinary budget for the 1920 period" at the total of 21,770 million francs. The budget voted July 15, 1914 foresaw receipts for 5,191.6 million francs (against 5,191.6 million francs in expenditures); but in the receipts, the loans amounted to 298 million francs and moreover there was expected an exceptional receipt of 112.5 million francs. For 1913, the receipts expected had been 4,738.8 million francs. At any rate, the following is a comparative table of the expenditures and receipts executed from 1903 to 1912 (in millions of francs).

$\begin{array}{cccr}\text { Period } & \text { Receipts } & \begin{array}{c}\text { Expendi- } \\ \text { tures }\end{array} & \begin{array}{c}\text { Surplus or } \\ \text { Deficiency }\end{array} \\ & & & \\ 1903 & \mathbf{3 , 6 6 7 . 6} & \mathbf{3 , 5 9 7 . 2} & +70,330.5 \\ 1904 & \mathbf{3 , 7 3 9 . 0} & \mathbf{3 , 6 3 8 . 5} & +\mathbf{1 0 0 , 5 2 2 . 2} \\ 1905 & \mathbf{3 , 7 6 6 . 3} & \mathbf{3 , 7 0 6 . 8} & +59,508.0 \\ 1906 & \mathbf{3 , 8 3 7 . 0} & \mathbf{3 , 8 5 2 . 0} & -15,009.3 \\ 1907 & \mathbf{3 , 9 6 8 . 4} & \mathbf{3 , 8 8 0 . 2} & +88,126.9\end{array}$

$\begin{array}{lllr}1908 & 3,966.4 & 4,020.5 & -54,144.6 \\ 1909 & 4,140.9 & 4,186.6 & -45,177.5 \\ 1910 & 4,273.9 & 4,321.9 & -48,027.8 \\ 1911 & 4,689.0 & 4,547.9 & +141,130.1 \\ 1912 & 4,857.5 & 4,742.8 & +114,735.1\end{array}$

And here is seen the important progression of the receipts of the government between years anterior to 1914 and 1920:

$19145,191.6$ millions in 1914 (estimated) $192021,770.0$ millions in 1920 (estimated)

16,578.4 million francs increase

Moreover, in the increase, there are a certain number of billions which do not represent, strictly speaking, receipts, e.g., the liquidation of war stocks for four billion francs. During the period 1914-1919, no budget was voted. The Chambres simply granted the government large votes of credit in confidence, called provisional credits. ${ }^{1}$ The budget of receipts was not made out. Moreover, the accounts of the war period are very

\footnotetext{
1 The first step in a return to the regular budget methods was the vote of the law of August 12, 1919, fixing the ordinary budget of civil services of the fiscal period 1919. There was no estimate of receipts.
} 